\title{
Posterior-assisted levitation in a modified way for nucleus retrieval after posterior capsule rupture
}

\author{
Narayan Bardoloi, ${ }^{1}$ Sandip Sarkar 0 , , ${ }^{2}$ Pranob Kalita, ${ }^{1}$ Amit Kumar Deb ${ }^{2}$
}

${ }^{1}$ Cataract \& Cornea Services, Chandraprabha Eye Hospital, Jorhat, Assam, India ${ }^{2}$ Ophthalmology, Jawaharlal Institute of Post Graduate Medical Education \& Research, Puducherry, Puducherry, India

\section{Correspondence to}

Dr Sandip Sarkar;

drsandip19@gmail.com

Accepted 2 November 2021

Check for updates

(c) BMJ Publishing Group Limited 2021. No commercial re-use. See rights and permissions. Published by BMJ.

To cite: Bardoloi N, Sarkar S, Kalita $\mathrm{P}$, et al. BMJ Case Rep 2021;14:e247245. doi:10.1136/bcr-2021247245

\section{DESCRIPTION}

Dropped nuclear or cortical material into the posterior vitreous or retina cannot be rescued by the anterior approach and demands a posterior segment approach. ${ }^{1}$ Any attempt to aspirate or impale the descending nucleus with the phacoemulsification tip can cause an excessive amount of traction on the vitreous, resulting in retinal breaks and subsequent retinal detachment. ${ }^{2}$ Packard and Kinnear $^{3}$ described the posterior-assisted levitation (PAL) technique where a cyclodialysis spatula was inserted through pars plana sclerotomy to levitate the descending nucleus into the anterior chamber (AC). Chang and Packard ${ }^{4}$ modified the technique with an injection of Viscoat (sodium hyaluronate 3\%-chondroitin sulfate 4\%) through the pars plana route and used the same cannula to elevate the descending nucleus. We now describe a modified method of PAL where a $23 \mathrm{G}$ vitrector of phacoemulsification machine (Centurion Vision System, Alcon Laboratories, USA) was used to levitate the descending nucleus. This technique makes a pars plana entry immediately after posterior capsular rent (PCR) and introduces a $23 \mathrm{G}$ vitrector through that route. After performing a thorough anterior vitrectomy around the nucleus, we levitate the nucleus into the AC with the help of the same vitrector.

\section{Surgical technique}

As soon as we had detected the PCR, we stopped all activities inside the eye, and the irrigating handpiece was kept in irrigation mode (figure 1A, video 1). The second instrument was withdrawn, and a generous amount of dispersive Ophthalmic Viscosurgical Devices (OVD) was injected before withdrawing the phaco probe (figure 1B). Dispersive OVD was injected to minimise the vitreous prolapse, plug the PCR area and avoid a further extension of the PCR. After stabilising the AC, we tried to locate the magnitude of PCR, level of the descending nucleus, vitreous prolapse and integrity of the anterior capsular margin. A microvitreoretinal (MVR) blade was introduced at the opposite clock hour of the main incision through the pars plana route $3.5 \mathrm{~mm}$ from the limbus and directed towards the mid-vitreous cavity (figure 1C). A $23 \mathrm{G}$ anterior vitrectomy cutter was introduced through the pars plana entry to support the sinking nucleus (figure 1D). A lower IOP (IOP $20 \mathrm{~mm} \mathrm{Hg}$ ) was kept in the Centurion Vision System. The bimanual irrigation and aspiration (I/A) irrigation cannula was placed in the AC to maintain the infusion. The vitrectomy parameters were set at cut rate $4000 / \mathrm{sec}$, vacuum $200-250 \mathrm{~mm} \mathrm{Hg}$ and flow rate of $18-20 \mathrm{cc} /$ sec. Anterior vitrectomy was performed through the pars plana approach below and around the nucleus to ensure removal of all the vitreous strands in the $\mathrm{AC}$ and around the nucleus (figure 2A). The nucleus was then levitated to the $\mathrm{AC}$ with the same vitrector (figure 2B). The irrigating cannula (figure 2C) or the chopper (figure 2D) supported the nucleus from above. A sufficient amount of dispersive OVD was injected above and below the nuclear fragments to protect the corneal endothelium (figure $3 \mathrm{~A}$ ). Keeping the iris spatula below the nucleus, slow motion emulsification of the remaining nuclear pieces was then performed at a low flow rate (figure 3B). ${ }^{5}$ Triamcinolone acetonide was used to stain any residual vitreous in the $\mathrm{AC}$, and the vitrector subsequently removed it. Bimanual irrigation aspiration was used to aspirate the remaining cortex (figure 3C). Cohesive OVD (1.4\% sodium hyaluronate) was injected in-between the iris and anterior capsular margin. A three-piece intraocular lens was implanted in the ciliary sulcus (figure 3D). Intracameral preservative-free $0.5 \%$ moxifloxacin (Vigamox, Alcon laboratories) was injected. The main incision was secured by $10-0$ nylon suture, and side port incisions were closed by stromal hydration. The sclerotomy site was closed with $8-0$ proline suture. An indirect ophthalmoscope (IO) was performed at the end of the surgery to rule out any cortical matter or nuclear fragment drop.

We did not use this technique and attempt to retrieve the nucleus or nuclear fragments in cases

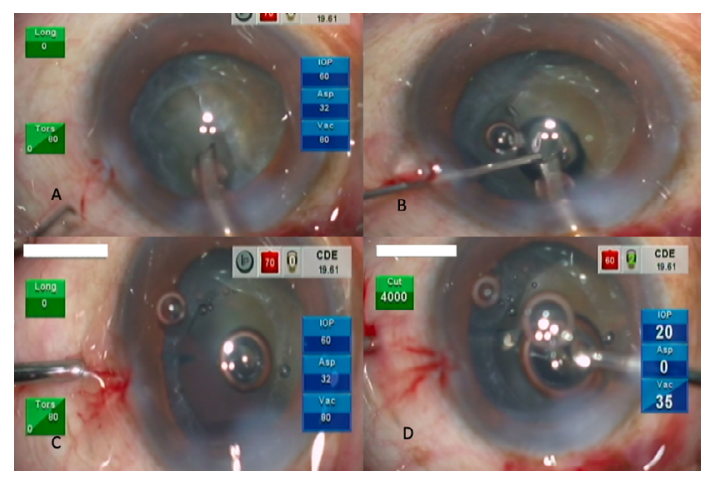

Figure 1 (A) As soon as the posterior capsule rupture was detected, we stopped all activities inside the eye and irrigating handpiece was kept in irrigation mode, (B) dispersive OVD was injected before withdrawing the phaco probe, $(C)$ a pars plana entry made with a microvitreoretinal blade, (D) $23 \mathrm{G}$ vitrector introduced through the pars plana route to support the sinking nucleus. 


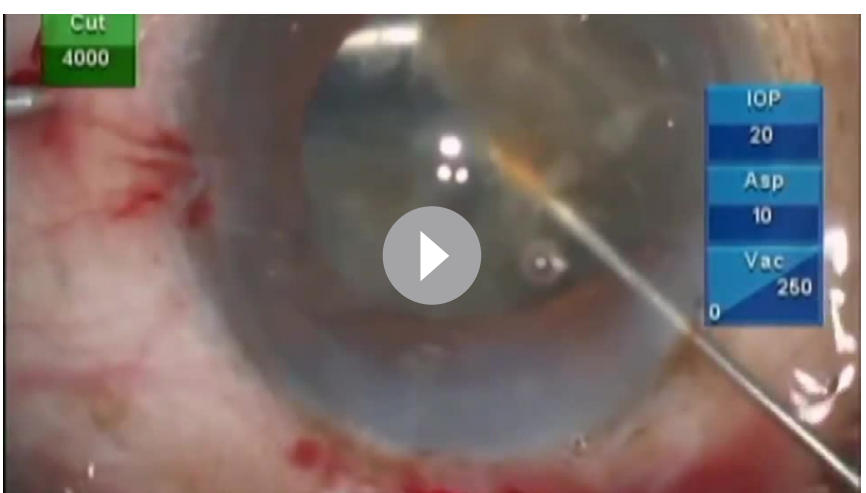

Video 1 Edited video showing the steps of modified posterior-assisted levitation technique.

where the nucleus had already dropped into the mid or posterior vitreous cavity. All such cases have been referred to the vitreoretina (VR) surgeon. This technique was used only when the nucleus was still in the anterior vitreous. We also recommend that the cataract surgeon should aim to abandon the surgery and prepare to refer the case to a VR surgeon if the nucleus drops further down into the mid or posterior vitreous cavity during the procedure. We hypothesised that performing the anterior vitrectomy via the pars plana approach will minimise the chances of vitreous traction during levitation compared with the other techniques of PAL described in the literature. ${ }^{6}$ Surgery can also be completed at ease in a single sitting using this modified technique. It can be a significant boon for cataract surgeons in a country like India, where VR facilities are not easily available. The anterior segment surgeons can replicate the steps and expect successful visual outcomes in such complications. However, we emphasise performing detailed IO examination at the end of the surgery to identify any cortex or nuclear fragment drop. We also recommend performing dilated fundus evaluation during the subsequent postoperative follow-up visits in these cases to identify any retinal break at the earliest that may have resulted from the intraoperative manipulation.

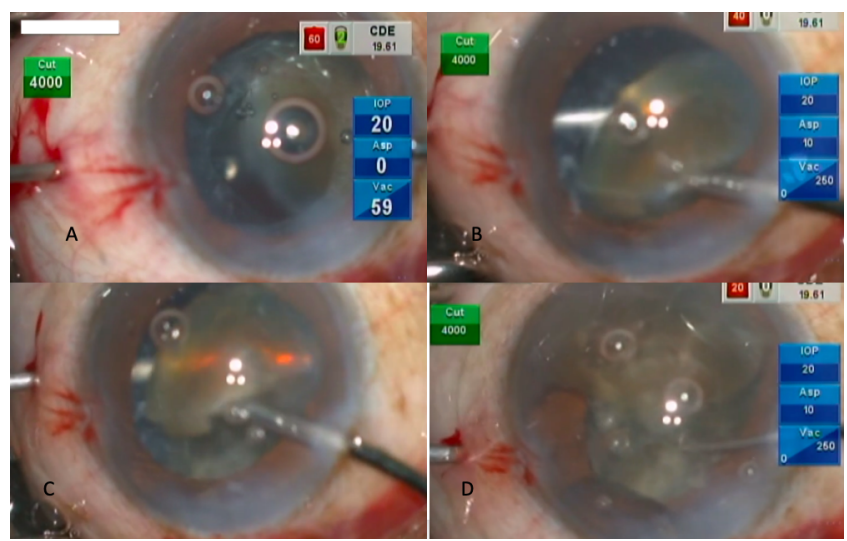

Figure 2 (A) Through anterior vitrectomy was performed below the fragments to remove all the vitreous strands, (B) levitation of nuclear fragments done with the same vitrector, $(C)$ the irrigating handpiece or (D) chopper was used to support the nucleus from above.

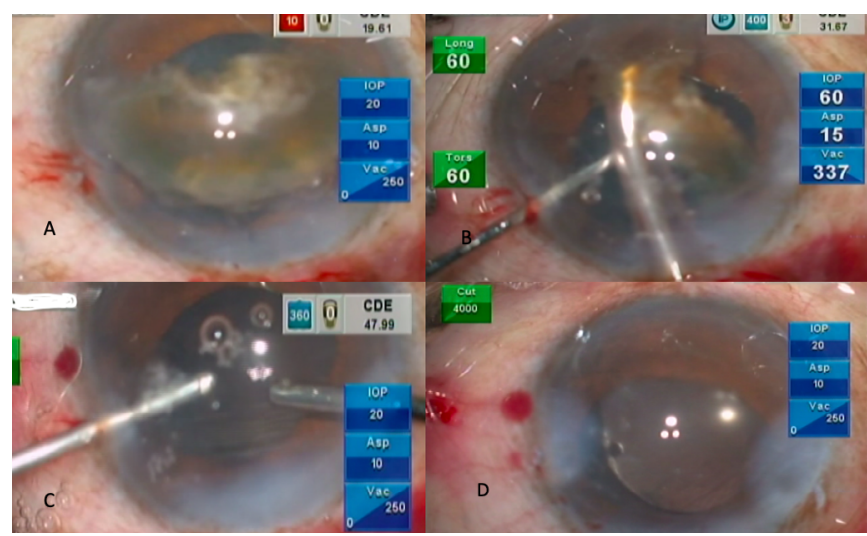

Figure 3 (A) The nuclear fragment reposited above the iris and dispersive OVD was injected above and below the nuclear fragments, (B) keeping the iris spatula below the fragments, a low flow rate, slow motion emulsification of the remaining nuclear fragments was performed, (C) bimanual irrigation and aspiration were used to remove the remaining cortical matter, (D) a three-piece intraocular lens was implanted over the sulcus. OVD, Ophthalmic Viscosurgical Devices.

\section{Learning points}

- Various techniques (Packard et al, Chang et al) have been described to levitate the dropping nucleus from the anterior vitreous cavity into the AC. However, these techniques have an inherent risk of causing intraoperative vitreous traction. These techniques are best performed at the hands of the most experienced surgeons.

- We describe a modified technique of levitation of the nucleus using a vitreous cutter through the pars plana approach which helps to reduce intraoperative traction on the posterior vitreous.

- This technique is recommended only when the nucleus is still in the anterior vitreous. Anytime the nucleus is noted to descend into the mid or posterior vitreous cavity, the surgeon should abandon the procedure and refer the case to a vitreoretina surgeon.

- Meticulous intraoperative and postoperative fundus examination using indirect ophthalmoscope is, however, recommended in all such cases.

Contributors NB contributed to patient care, decision making, performed surgery and manuscript writing. SS contributed to data collection and data analysis. PK contributed to patient care and manuscript writing. AKD contributed to manuscript review and manuscript writing.

Funding The authors have not declared a specific grant for this research from any funding agency in the public, commercial or not-for-profit sectors.

Competing interests None declared.

Patient consent for publication Consent obtained directly from patient(s).

Provenance and peer review Not commissioned; externally peer reviewed.

Case reports provide a valuable learning resource for the scientific community and can indicate areas of interest for future research. They should not be used in isolation to guide treatment choices or public health policy.

\section{ORCID iD}

Sandip Sarkar http://orcid.org/0000-0002-9882-0407 


\section{REFERENCES}

1 Kwok AKH, Li KKW, Lai TYY, et al. Pars plana vitrectomy in the management of retained intravitreal lens fragments after cataract surgery. Clin Exp Ophthalmol 2002;30:399-403.

2 Gilliland GD, Hutton WL, Fuller DG. Retained intravitreal lens fragments after cataract surgery. Ophthalmology 1992;99:1263-9.
3 Packard RB, Kinnear FC. Manual of cataract and intraocular lens surgery. Churchill Livingstone, 1991.

4 Chang DF, Packard RB. Posterior assisted levitation for nucleus retrieval using Viscoat after posterior capsule rupture. J Cataract Refract Surg 2003;29:1860-5.

5 Osher RH. Slow motion phacoemulsification approach. J Cataract Refract Surg 1993;19:667.

6 Schutz JS, Mavrakanas NA. Posterior-assisted levitation in cataract surgery. Curr Opin Ophthalmol 2010;21:50-4.

Copyright 2021 BMJ Publishing Group. All rights reserved. For permission to reuse any of this content visit https://www.bmj.com/company/products-services/rights-and-licensing/permissions/

BMJ Case Report Fellows may re-use this article for personal use and teaching without any further permission.

Become a Fellow of BMJ Case Reports today and you can:

- Submit as many cases as you like

- Enjoy fast sympathetic peer review and rapid publication of accepted articles

- Access all the published articles

Re-use any of the published material for personal use and teaching without further permission

\section{Customer Service}

If you have any further queries about your subscription, please contact our customer services team on +44 (0) 2071111105 or via email at support@bmj.com.

Visit casereports.bmj.com for more articles like this and to become a Fellow 